\title{
EXTREME EVENTS OF PRECIPITATION AND OCCURRENCES OF FLOODING, RUNOFF AND INUNDATION IN THE METROPOLITAN REGION OF CURITIBA, BRAZIL ${ }^{1}$
}

\author{
EVENTOS EXTREMOS DE PRECIPITAÇÃO E OCORRÊNCIAS DE \\ ALAGAMENTOS, ENXURRADAS E INUNDAÇÕES NA REGIÃO \\ METROPOLITANA DE CURITIBA, BRASIL
}

\section{EVENTOS EXTREMOS DE PRECIPITACIÓN Y OCURRENCIAS DE ALUVIÓNES, DILUVIOS Y INUNDACIONES EN LA REGIÓN METROPOLITANA DE CURITIBA, BRASIL}

\author{
Nathan Felipe da SILVA CALDANA ${ }^{2}$ \\ Leonardo RODRIGUES ${ }^{3}$ \\ Luis Gustavo BATISTA FERREIRA ${ }^{4}$ \\ Marcelo Augusto de AGUIAR e SILVA ${ }^{5}$
}

\begin{abstract}
Extreme precipitation events cause severe damage in both urban and rural areas. The objective of this work was to analyze rainfall variability, understand the dynamics of extreme precipitation events and to find out the occurrence of floods, runoff and inundation in the Metropolitan Region of Curitiba (MRC). Data from 39 rainfall stations distributed in the MRC area were used, as well as data by municipality of occurrence of flooding, runoff or inundation, from 1976 to 2018 . Extreme precipitation events were identified in all months, most frequently in the summer. Totaling 48 decrees of emergency or public calamity and 397,516 people affected by one of the three socioenvironmental disasters.
\end{abstract}

Keywords: Vulnerability; Climate risk; Natural disasters.

Resumo: Os eventos extremos de precipitação causam severos danos no espaço urbano e rural. O objetivo deste trabalho foi analisar a variabilidade pluviométrica, compreender a dinâmica dos eventos extremos de precipitação e averiguar as ocorrências de alagamentos, enxurradas e inundações na Região Metropolitana de Curitiba (RMC). Utilizou-se dados de 39 estações pluviométricas distribuídas na RMC, além de dados por município de ocorrência de alagamentos, enxurradas ou inundações, de 1976 a 2018. Os eventos extremos de precipitação foram identificados em todos os meses, com maior frequência no verão. Foram 48 decretos de situação de emergência ou calamidade pública e 397.516 pessoas afetadas por um dos três desastres socioambientais.

Palavras-chave: Vulnerabilidade; Risco climático; Desastres naturais.

\footnotetext{
${ }^{1}$ Research level: Doctorate. Funding: (CAPES - Coordenação de Aperfeiçoamento de Pessoal de Nível Superior)

${ }^{2} \mathrm{PhD}$ student in Agronomy - Research line: Agrometeorology. In the Postgraduate Program in Agronomy at the State University of Londrina. E-mail: nathancaldana @ gmail.com

${ }^{3}$ Graduating in geography Agronomy at the State University of Londrina. E-mail: leonardo.rodrigues @ uel.br

${ }^{4} \mathrm{PhD}$ student in Agronomy. In the Postgraduate Program in Agronomy at the State University of Ponta Grossa.

E-mail: luiz.gustavo@agronomo.eng.br

${ }^{5} \mathrm{PhD}$ in Agronomy (Irrigation and Drainage) at the State University Paulista Júlio de Mesquita Filho. Adjunct professor of the agronomy course. E-mail: aguiaresilva@uel.br 
Resumén: Los eventos extremos de precipitación causan severos daños en el espacio urbano y rural. El objetivo de este trabajo fue analizar la variabilidad de la lluvia, comprender la dinámica de los eventos extremos de precipitación y averiguar las ocurrencias de inundaciones, aluviónes y diluvios en la Región Metropolitana de Curitiba (RMC). Se utilizaron datos de 39 estaciones pluviométricas distribuidas en la RMC, además de datos por municipio de ocurrencia de inundaciones, aluviónes o diluvos de 1976 a 2018. Los eventos extremos de precipitación fueron identificados en todos los meses, con mayor frecuencia en el verano. Fueron 48 decretos de situación emergenciales o calamidad pública y 397.516 personas afectadas por uno de los tres desastres socioambientales.

Palabras Clave: Vulnerabilidad; Riesgo climático; Desastres naturales.

\section{Introduction}

Natural disasters, as one of the key consequences of extreme episodes of precipitation, are defined as natural phenomena that shape and transform the landscape and geographical space (MANCILLAS et al., 2015; CARVALHO et al., 2017). If these intensify in the social environment, they can generate situations of potential harmer, causing deaths and material losses (DAMASCENA et al. 2017; MACHADO et al. 2017). The cases of floods are the main event and the most common among hydroclimatological events. Flooding represents $59 \%$ of the cases of occurrence due to extreme weather events (MARCELINO, 2007; CALDANA et al., 2018). Such hydroclimatological events occur in more than $80 \%$ of Brazilian cities and are associated with severe atmospheric instabilities (MARCELINO, 2007). Several works around the world demonstrate the importance of understanding the rainfall regime and variability for sustainable urban development (PANDOLFO et al. 2017; PASSOS et al. 2017; DOS REIS et al. 2017; ALBUQUERQUE et al., 2018; CONCEIÇÃO et al. 2018; GELCER et al. 2018; HUANG et al., 2018; DE MATOS et al. 2018; SANTI et al., 2018; DE SOUSA e DE OLIVEIRA, 2018; DE SOUZA et al., 2018; TAYT'SOHN et al., 2018).

Extreme climatic events act in the scope of the main causes of natural catastrophes that affect man, since, the way societies organize themselves disregards the rhythm and variability of the atmospheric system (VICENTE, 2005). Every year, natural disasters result in numerous deaths, injuries, in addition, as costly economic losses (MARCELINO, 2007; HUANG et al. 2018; TSAVDAROGLOU, 2018; WOSSEN, 2018).

The spaces are affected by natural phenomena in a homogeneous way, but the socioenvironmental vulnerability exposes the population to the different risks (ALCÁNTARAAYALA, 2002). The condition of population poverty is closely linked to the condition of risk 
formation and socio-environmental vulnerability (MENDONÇA, 2005). The occupation of irregular areas and the risk associated with socioeconomic conditions increases the consequences of disasters and the impacts on social groups. For this context, a phenomenon can affect a region and affect the population living there differently (CIDADE et al., 2013; FREIRE et al., 2014; GRIGOLETTI et al. 2018).

Thus, the objective of this work was to understand the rainfall variability and the dynamics of extreme precipitation events, in addition, to analyzing the occurrences of floods, inundation and runoff in the MRC - Metropolitan Region of Curitiba, Paraná State, Brazil. Therefore, were aim to analyze the rainfall of the MRC by annual and monthly variability and extreme daily events, identifying greater heights of rain concentrated in the 24-hour interval.

\section{Material and Methods}

For this, were used data from 35 weather stations, being them from the Instituto Agronômico do Paraná (IAPAR), the Instituto Nacional de Meteorologia (INMET), the Agência Nacional das Águas (ANA) and the Águas Paraná, during 1976 to 2018 (Table 01). The stations are distributed along the MRC (Metropolitan Region of Curitiba) area and in neighboring municipalities to contribute to the interpolation map in the neighboring areas (Figure 01).

Were used Box Plot to complement the analysis of rainfall variability and detection of extremes. The main resource obtained in its use is "to provide a quick view of the data distribution. If the distribution is symmetrical, the box is balanced with the median positioned in the center of the box. For asymmetric distributions, there is an imbalance in the box in relation to the median" (SILVESTRE et al., 2014, p. 27). 
EM

QUESTÃO

pág. 143-164

Figure 1 - Localization of Metropolitan Region of Curitiba (MRC) and the weather stations.

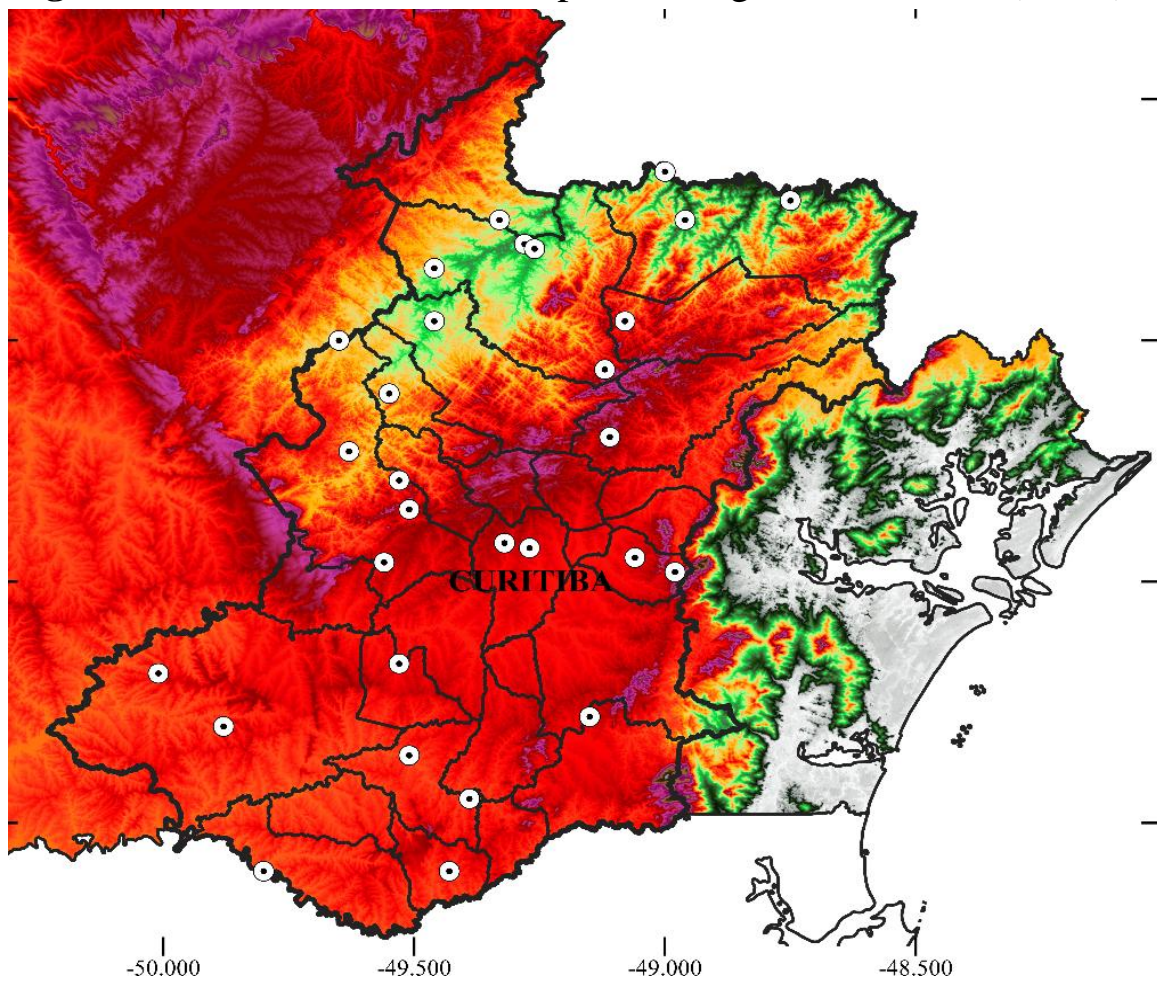
Legend

\& $\square$ Metropolitan Region of Curitiba

$\bullet$ Weather Stations Altitude $(\mathrm{m})$

Source: IBGE (2018); Org. authors (2018).

Table 1 - Data from the Weather Stations.

\begin{tabular}{c|c|c|c|c|c}
\hline Agency & Station (Municipality) & Longitude & Latitude & Altitude & Data Series \\
\hline ANA & Turvo (Doutor Ulysses) & -49.33 & -24.75 & $400 \mathrm{~m}$ & $(1976-2018)$ \\
\hline ANA & Doutor Ulisses (Doutor Ulysses)* & -49.41 & -24.56 & $818 \mathrm{~m}$ & $(1976-2018)$ \\
\hline ANA & Balsa do Cerro Azul (Cerro Azul) & -49.28 & -24.8 & $270 \mathrm{~m}$ & $(1976-2018)$ \\
\hline ANA & Cerro Azul & -49.26 & -24.81 & $320 \mathrm{~m}$ & $(1978-2018)$ \\
\hline ANA & Santa Cruz - Tigre (Cerro Azul) & -49.12 & -25.06 & $938 \mathrm{~m}$ & $(1976-2018)$ \\
\hline ANA & Tatupeva (Adrianópolis) & -48.75 & -24.71 & $230 \mathrm{~m}$ & $(1976-2018)$ \\
\hline ANA & Fazenda Boa Vista (Adrianópolis) & -48.96 & -24.75 & $227 \mathrm{~m}$ & $(1976-2018)$ \\
\hline ANA & Capela da Ribeira (Adrianópolis) & -49 & -24.65 & $180 \mathrm{~m}$ & $(1976-2018)$ \\
\hline ANA & Tunas (Tunas do Paraná) & -49.08 & -24.96 & $880 \mathrm{~m}$ & $(1976-2018)$ \\
\hline ANA & Ervalzinho (Itaperuçu) & -49.55 & -25.11 & $750 \mathrm{~m}$ & $(1976-2018)$ \\
\hline IAPAR & Itaqui (Campo Largo) & -49.56 & -25.46 & $901 \mathrm{~m}$ & $(1976-2018)$ \\
\hline ANA & Bateias (Campo Largo) & -49.51 & -25.35 & $890 \mathrm{~m}$ & $(1976-2018)$ \\
\hline ANA & Pinheirinho (Campo Largo)* & -49.65 & -25 & $517 \mathrm{~m}$ & $(1976-2018)$ \\
\hline ANA & Três Córregos & -49.63 & -25.23 & $800 \mathrm{~m}$ & $(1976-2018)$ \\
\hline ANA & Curitiba & -49.26 & -25.43 & $950 \mathrm{~m}$ & $(1976-2018)$ \\
\hline IAPAR & Piraquara & -49.06 & -25.45 & $900 \mathrm{~m}$ & $(1976-2018)$ \\
\hline ANA & Fazendinha (São José dos Pinhais) & -49.08 & -25.56 & $910 \mathrm{~m}$ & $(1976-2018)$ \\
\hline ANA & Ilha do Rio Claro (São José dos Pinhais)* & -48.9 & -25.81 & $237 \mathrm{~m}$ & $(1976-2018)$ \\
\hline IAPAR & Pedra Alta (Lapa) & -49.88 & -25.8 & $903 \mathrm{~m}$ & $(1976-2018)$ \\
\hline ANA & Pedra Lisa (Lapa) & -50.01 & -25.69 & $910 \mathrm{~m}$ & $(1976-2018)$ \\
\hline ANA & Quitandinha & -49.51 & -25.86 & $820 \mathrm{~m}$ & $(1976-2018)$ \\
\hline
\end{tabular}


$\mathrm{EM}$

QUESTÃO

$\mathrm{V} .14 \diamond \mathrm{N} .02 \diamond 2021$

pág. 143-164

\begin{tabular}{c|c|c|c|c|c}
\hline ANA & Rio da Várzea dos Lima (Quitandinha) & -49.39 & -25.95 & $800 \mathrm{~m}$ & $(1976-2018)$ \\
\hline ANA & Rincão (Tijucas do Sul) & -49.15 & -25.78 & $913 \mathrm{~m}$ & $(1976-2018)$ \\
\hline ANA & Rio Negro* & -49.8 & -26.1 & $824 \mathrm{~m}$ & $(1976-2018)$ \\
\hline IAPAR & Fragosos (Piên) & -49.38 & -26.15 & $790 \mathrm{~m}$ & $(1976-2014)$ \\
\hline ANA & Guaiaca (São João do Triunfo) & -50.2 & -25.61 & $856 \mathrm{~m}$ & $(1976-2018)$ \\
\hline ANA & Mandaçaia (Palmeira) & -50.06 & -25.48 & $950 \mathrm{~m}$ & $(1976-2018)$ \\
\hline ANA & Vieiras (Palmeira) & -50.29 & -25.47 & $892 \mathrm{~m}$ & $(1976-2018)$ \\
\hline ANA & Porto Amazonas & -49.88 & -25.55 & $793 \mathrm{~m}$ & $(1976-2018)$ \\
\hline ANA & Abapã (Castro) & -49.83 & -24.93 & $1007 \mathrm{~m}$ & $(1976-2018)$ \\
\hline ANA & Itaiacoca (Ponta Grossa) & -49.9 & -25.13 & $975 \mathrm{~m}$ & $(1976-2018)$ \\
\hline ANA & Morretes (IAPAR) & -48.49 & -25.3 & $59 \mathrm{~m}$ & $(1976-2018)$ \\
\hline ANA & Morretes (ANA) & -48.83 & -25.46 & $8 \mathrm{~m}$ & $(1976-2018)$ \\
\hline ANA & Antonina & -48.76 & -25.43 & $74 \mathrm{~m}$ & $(1976-2018)$ \\
\hline
\end{tabular}

Source - ANA e IAPAR (2019); Org. authors (2019). *Weather stations used to analyses by Box Plot

Box plots represent five classifications of values. Outliers are divided into outliers (values above the maximum, but not extreme) and extremes, with any value greater than Q3 + $1.5(\mathrm{Q} 3$ - Q1) or less than Q1 - 1.5 (Q3 - Q1). The highs and lows are considered the highest values in the series, but they are not extreme or outliers. Inside the box, three quartiles are classified with $25 \%$ of the data each, in addition to the median value, equivalent to the second quartile, or 50\% of the data (LEM et al., 2013; SCHNEIDER and DA SILVA, 2014).

For analysis using Box plot, data from four weather stations were used as a parameter, one at each end of the basin. Thus, Rio Negro (South), Pinheirinho - Campo Largo (Midwest), Rio Claro Island - São José dos Pinhais (East) and Doutor Ulysses (North) were used. The identification of daily extreme events was performed using the $99 \%$ percentile of annual precipitation, using the formula:

$$
\text { Eep }=\frac{P 99 / 12}{2}
$$

Eep being the extreme precipitation event;

P99, the Percentile $99 \%$ of annual precipitation

Precipitation appears to be characterized as extreme and must have occurred within 24 hours (Table 02). The graphics were created using the Sigma Plot software. 
Table 2 - Values used as parameter for extreme events identification.

\begin{tabular}{ccccc}
\hline Station & Doutor Ulysses & Rio Negro & Campo Largo & $\begin{array}{c}\text { São José dos } \\
\text { Pinhais }\end{array}$ \\
\hline Precipitation & 98,3 & 93,2 & 87,9 & 103,7 \\
\hline \multicolumn{4}{c}{ Source: Águas Paraná; ANA; IAPAR e INMET (2019); Org. authors (2019) }
\end{tabular}

Source: Águas Paraná; ANA; IAPAR e INMET (2019); Org. authors (2019)

To identify the occurrences of floods, runoff and floods, data from the Civil Defense of Paraná were used. The Brazilian Civil Protection acts according to the need for emergency and service to be provided by assisting the affected populations. The action is immediate after the disaster, and the teams sent to the field are responsible for completing a report describing the phenomenon and the resulting damage (MARTINS et al., 2017). The Defense of Paraná State is structured by eight Regional Civil Defense Coordinators, each municipality having its Municipal Civil Defense Coordination. The data were obtained by the Report of Occurrence of flooding, runoff and flooding. The data collected were numbers of occurrences, people affected and decrees of emergency and public calamity.

\section{Results and Discussion}

The average rainfall in the MRC (Figure 02) exhibited a significant regional difference. In the Northern central area of the MRC the minimum values are $1300 \mathrm{~mm}$, while in a short distance the Eastern area is $2050 \mathrm{~mm}$.

This discrepancy between the average values of precipitation in the region is due to Mountain of the Sea, which covers this area of the MRC and, consequently, contribute to the difference in the topography and its altitudes (Figure 01). The highest peaks in the mountain region reach $1850 \mathrm{~m}$, while in other areas of the region the average altitude is $900 \mathrm{~m}$. This factor linked to maritimity, which causes orographic rains on the slopes of the mountains facing the Atlantic and makes them more humid than those facing the continent. Thus, depending on the intensity of the water steam transport, the cloud can evolve and give rise to precipitations that are wide in the windward slope and reduce the wind (VANHONI and MENDOÇA, 2008; COUTO et al. 2016; LEE et al. 2018). 
Figure 2 - Average annual rainfall in the Metropolitan Region of Curitiba (1976 - 2018).

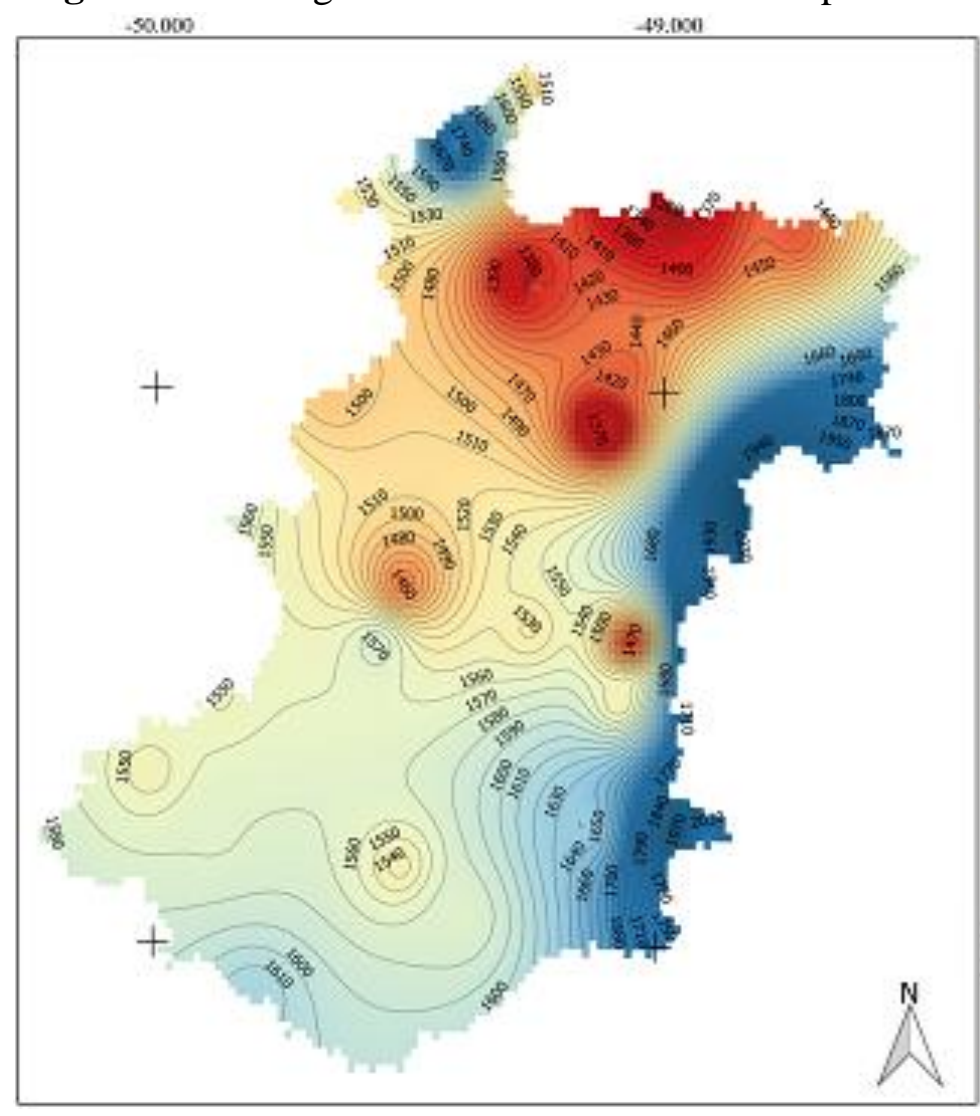

\section{Legend}

$\square$ Metropolitan Region of Curitiba

Average annual rainfall

$1380-1425 \mathrm{~mm}$

$1425-1465 \mathrm{~mm}$

$1465-1510 \mathrm{~mm}$

$1510-1555 \mathrm{~mm}$

$1555-1600 \mathrm{~mm}$

$1600-1650 \mathrm{~mm}$

$1650-1700 \mathrm{~mm}$

Q $1700 \mathrm{~mm}<$
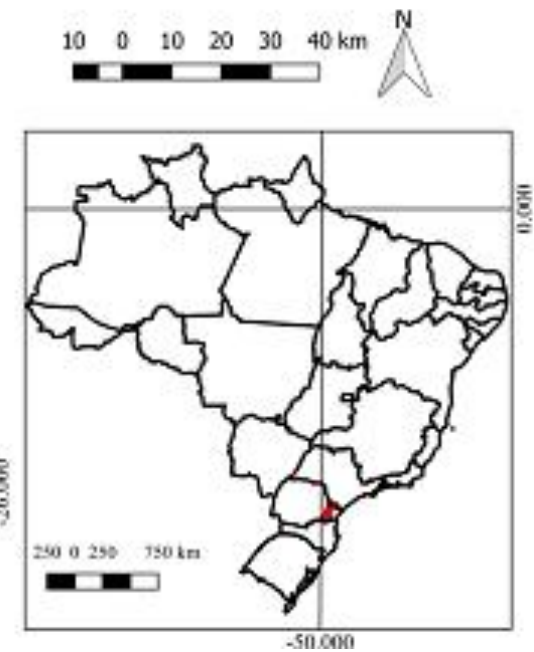

Source: Águas Paraná; ANA; IAPAR e INMET (2019); Org. authors (2019).

Latitude also proved to be a determining factor in the precipitation of the region, since the Southern region, close to the Iguaçu River channel showed average values from 1500 to $1600 \mathrm{~mm}$, while the Northern area exhibited values from 1300 to $1400 \mathrm{~mm}$.

In order to improve and complement the analysis of rainfall variability, a Box Plot graph was created to identify the variation in annual precipitation in the MRC (Figure 03). It was possible to verify a great discrepancy between the pluviometric heights in the station of the mountainous area (São José dos Pinhais) for the others. In this station, a maximum value of $2820 \mathrm{~mm}$ was observed, not being considered a discrepant value. While the lowest observed value was $1380 \mathrm{~mm}$, being extremely higher than other stations.

The variation of the box in the ranges of $25 \%$ to $75 \%$ was from $1790 \mathrm{~mm}$ to 2380 mm, respectively. 
Figure 3 - Box plot of annual precipitation (mm) of the Metropolitan Region of Curitiba (1976 - 2018).

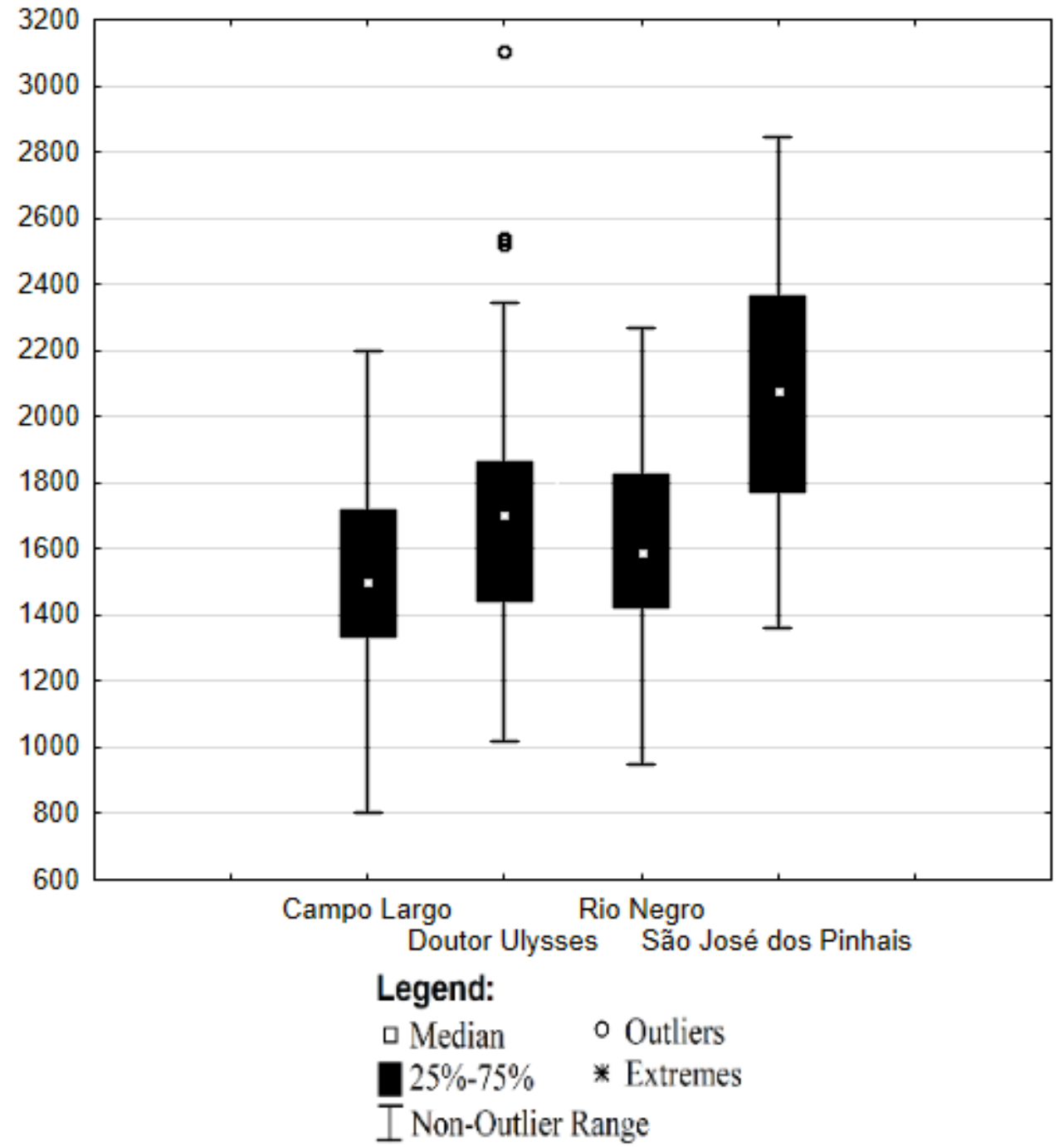

Source: Águas Paraná; ANA; IAPAR e INMET (2019); Org. authors (2019).

The other three stations do not exhibit significant differences in annual rainfall variability. It is should be noted that at the Doutor Ulysses station there were four discrepancies, higher than $3,000 \mathrm{~mm}$. The discrepancies did not affect the median value of this station, being $1,650 \mathrm{~mm}$, with little difference for the other two stations.

The highest annual rainfall recorded in the four stations, including the one above 3,000 mm, occurred in 1983, with the magnitude of this year average rainfall in the Parana State being highlighted in several studies (MINUZZI e CARAMORI, 2015; NASCIMENTO JUNIOR and SANT'ANNA NETO, 2016; CALDANA et al., 2018; CALDANA et al., 2019).

The Campo Largo station, located in the Central-Western area of the MRC was identified as the driest, with a median of $1,450 \mathrm{~mm}$. The station had no discrepancy and showed $25 \%$ and $75 \%$ quartile variation from $1,380 \mathrm{~mm}$ to $1,710 \mathrm{~mm}$. The lowest annual 
rainfall recorded at the station was $805 \mathrm{~mm}$, the lowest in the series analyzed for all weather stations.

Monthly (figure 04) the weather stations exhibited a similar distribution, during the months of the Spring and Summer and for the months of Fall and Winter, drier. The station with the highest rainfall was São José dos Pinhais. Four extreme values were identified, during January, June and September, and eleven discrepancies, one in the lower area of the box plot, in June. There were two months without precipitation in the analyzed series, both occurrences were in August.

Figure 4 - Box plot of monthly precipitation in the Metropolitan Region of Curitiba (1976 - 2018).
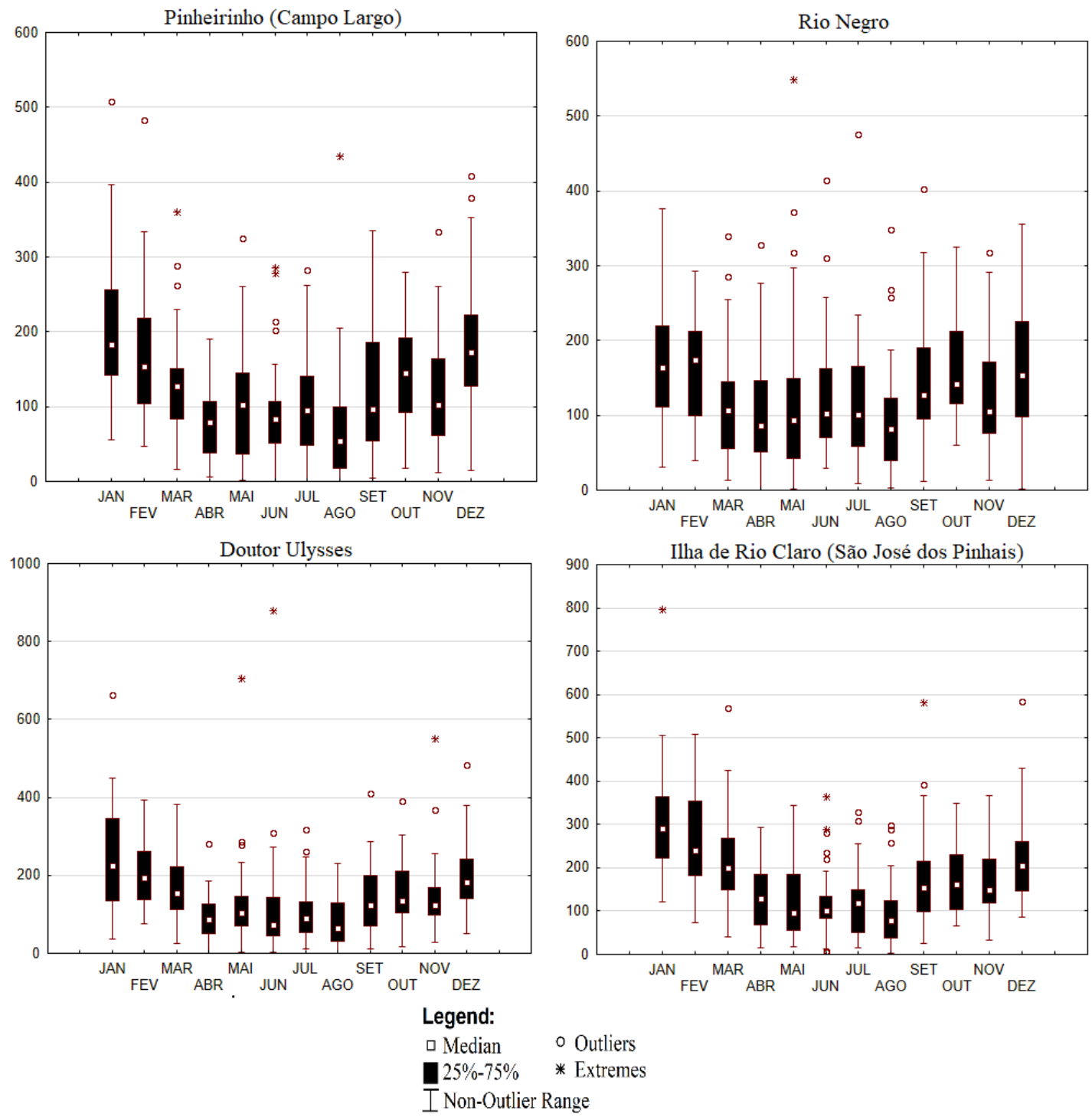

Source: Águas Paraná; ANA; IAPAR e INMET (2019); Org. authors (2019). 
For the Campo Largo station, four extreme values were observed in the months of March, June and August, in addition to eleven discrepancies. In addition, it was identified that in the months of April, May, June, July and August there were months without precipitation. The month of December showed the greatest precipitation monthly variation, ranging from 20 to $400 \mathrm{~mm}$.

The analysis of data from the Rio Negro station showed only one extreme value in May, in addition to thirteen discrepancies. The highest monthly variation was observed in December, with oscillations from 0 to $360 \mathrm{~mm}$. The months of April, May, August and December showed monthly occurrence without precipitation.

For the Doutor Ulysses station, the highest monthly precipitation height was identified, with $860 \mathrm{~mm}$ in June, in addition to two other discrepancies in the months of May and November. Altogether it was eleven months with discrepancies.

Were verified significant precipitations heights concentrated in 24 hours, with a greater number of occurrences in all the locations analyzed. Were observed with great frequency of high daily rainfall, which can become extreme precipitation events in the region. Thus, we used as a parameter the occurrences of half of the monthly average precipitation in the 24-hour interval (Figure 05).

For the Campo Largo Station was observed 37 extreme daily precipitation events were observed at Campo Largo station, mainly concentrated during the Summer, with an emphasis on January, with seven occurrences. In the region covered by this station, the formation of Convective Systems and Mesoscale Convective Complexes - MCC (CALDANA et al., 2018; CALDANA et al., 2019).

Convective Systems and MCCs operate along the year in the Southern region of Brazil but predominantly in the spring and summer seasons (BALDO et al., 2017; CALDANA et al., 2018; CALDANA et al., 2019), MCCs are identified in satellite images by their approximately circular shape and by a wide area of storm coverage. They are defined as a cluster of cumulunimbus covered by a dense cirrus layer, still being convective cloud systems, with rapid vertical and horizontal growth in a time interval of 6 to 12 hours (HOLLEMAN, 2001; KUNZ et al., 2009). Depending on their intensity, they can create several nuclei with the formation of storms and the incidence of hail. Their displacement along the Paraná State is normally in the Western - Eastern direction, coming from Paraguay (DAFIS et al., 2017; PUNGE et al., 2017; TREFAULT et al., 2018; CALDANA et al., 2018; CALDANA et al., 2019). It is should be noted that the altitudes of the region increase, in the 
Western-Eastern direction, which may contribute to the friction of the system with the topography, mainly in the region of Campo Largo (Figure 01).

Convective systems, on the other hand, are differentiated by the smaller spatial scope, formed by the process of heat transfer by conduction that occurs in intense vertical movements, leading to the rapid condensation process and the formation of Cumulunimbus (CALDANA et al., 2018; CALDANA et al., 2019). In both cases, precipitation is generally short-lived and of high intensity (SCAGLIONI and SARAIVA, 2004; DAFIS et al., 2017; TREFAULT et al., 2018). Therefore, the occurrence of extreme events per month in 4 weather stations was analyzed, namely Campo Largo, Doutor Ulysses, Rio Negro and São José dos Pinhais.

Figure 5 - Number of Occurrences of Extreme Rainfall Events in the Metropolitan Region of Curitiba (1976 - 2018).
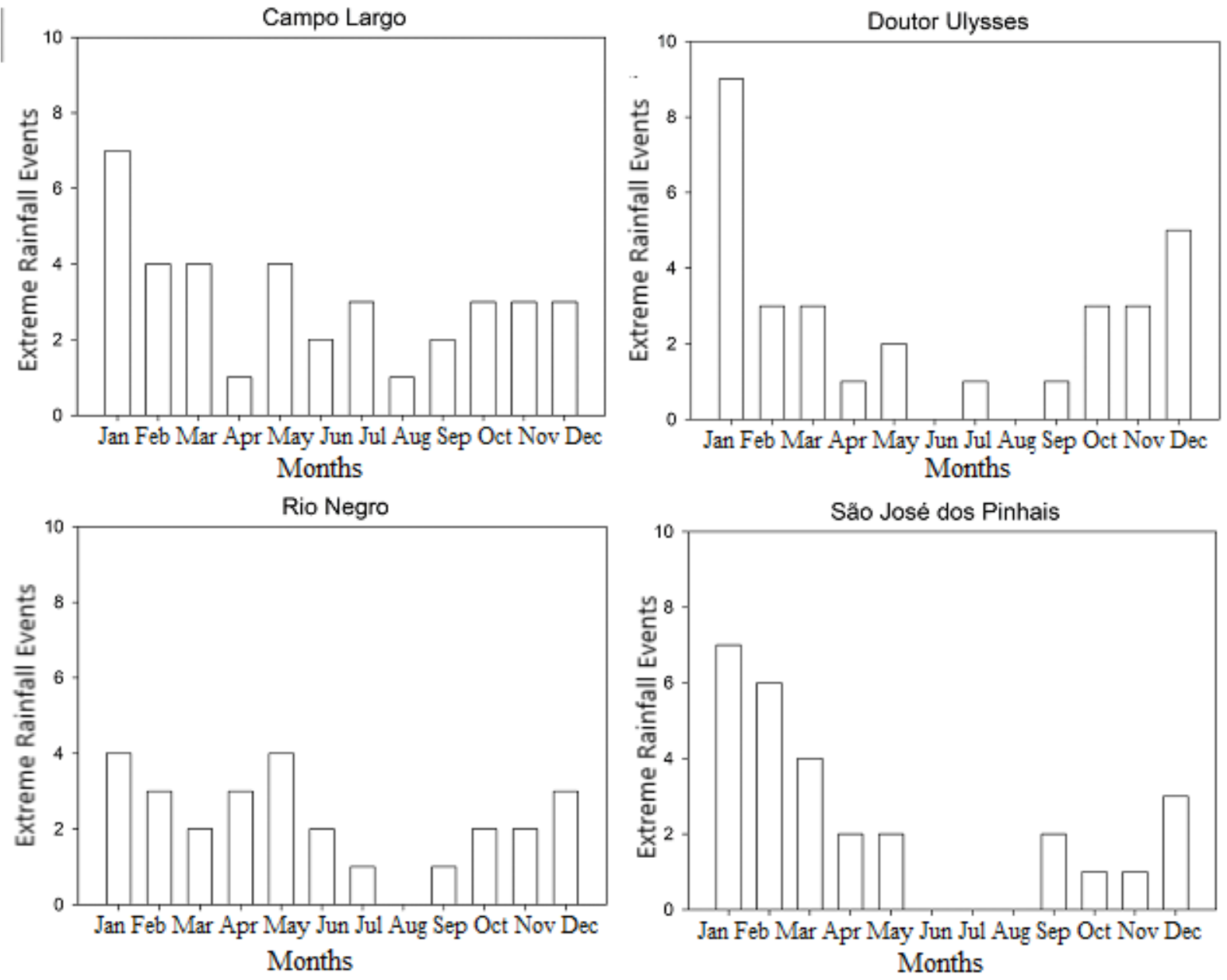

Source: Águas Paraná; ANA; IAPAR e INMET (2019); Org. authors (2019). 
At Doutor Ulysses station, 31 extreme events were detected and their distribution was similar to that of Campo Largo, with a predominance of events during the Summer. The highest incidence was also in January, with nine occurrences. There were few extreme events between June and November.

The Rio Negro station showed slightly different incidences from the others, with emphasis on the number of occurrences in the Fall and Winter months, concentrated mainly in the month of May.

For these weather stations, a large part of the rainfall of this region is formed by the entry of Polar Air Masses that collide with the hot continental air, generating cold fronts and strong atmospheric instability, which can lead to the formation of cumulunimbus and lead to the formation of strong storms and hail formation. In these cases, precipitation is normally longer and less intense than in the formation of Convective Systems and MCC formed in the Spring and Summer months (BEREZAUK and SANT'ANNA NETO, 2006; PUNGE and KUNZ, 2016; BEREZUK, 2017; CALDANA et al., 2018). Thus, it is possible to justify the volumes of rainfall concentrated in the winter months throughout the region.

The formation of active systems and the identification of extreme precipitation events were important to analyze and identify that greater rainfall heights in a short period of time occur frequently in the MRC and thus investigate some of the impacts of rain in the region. For this context, were used data on the occurrence of flooding, runoff or inundation in the municipalities (Figure 06). It was observed that all municipalities had at least one occurrence of the socio-environmental disasters from 1990 to 2018. There were 368 occurrences, with predominance in the central axis of the region, mainly in the municipalities around Curitiba. It is possible to identify that the occurrences are in places where there is a greater concentration of rainfall (Figure 02), mainly in São José dos Pinhais.

The most affected municipality was Curitiba with 46 occurrences in the analyzed period, with more than two occurrences per year. It should be noted that for the Civil Defense to provide assistance, it demonstrates that this occurrence has brought damage to society and / or the environment, and also that these events can occur more frequently, since not all incidences of one of the three phenomena may have had assistance from the Civil Defense.

South of Curitiba stand out the municipalities bordering São José dos Pinhais and Araucária, with 35 and 28 occurrences, respectively. In the North, Colombo and Almirante Tamandaré stand out with 23 and 25 occurrences, respectively. It is noteworthy that all of 
these registered more than one occurrence per year, demonstrating the socio-environmental vulnerability in Curitiba and its neighboring municipalities.

Figure 6 - Number of occurrences of floods, runoffs and inundations in the Metropolitan Region of Curitiba (1990 - 2018).
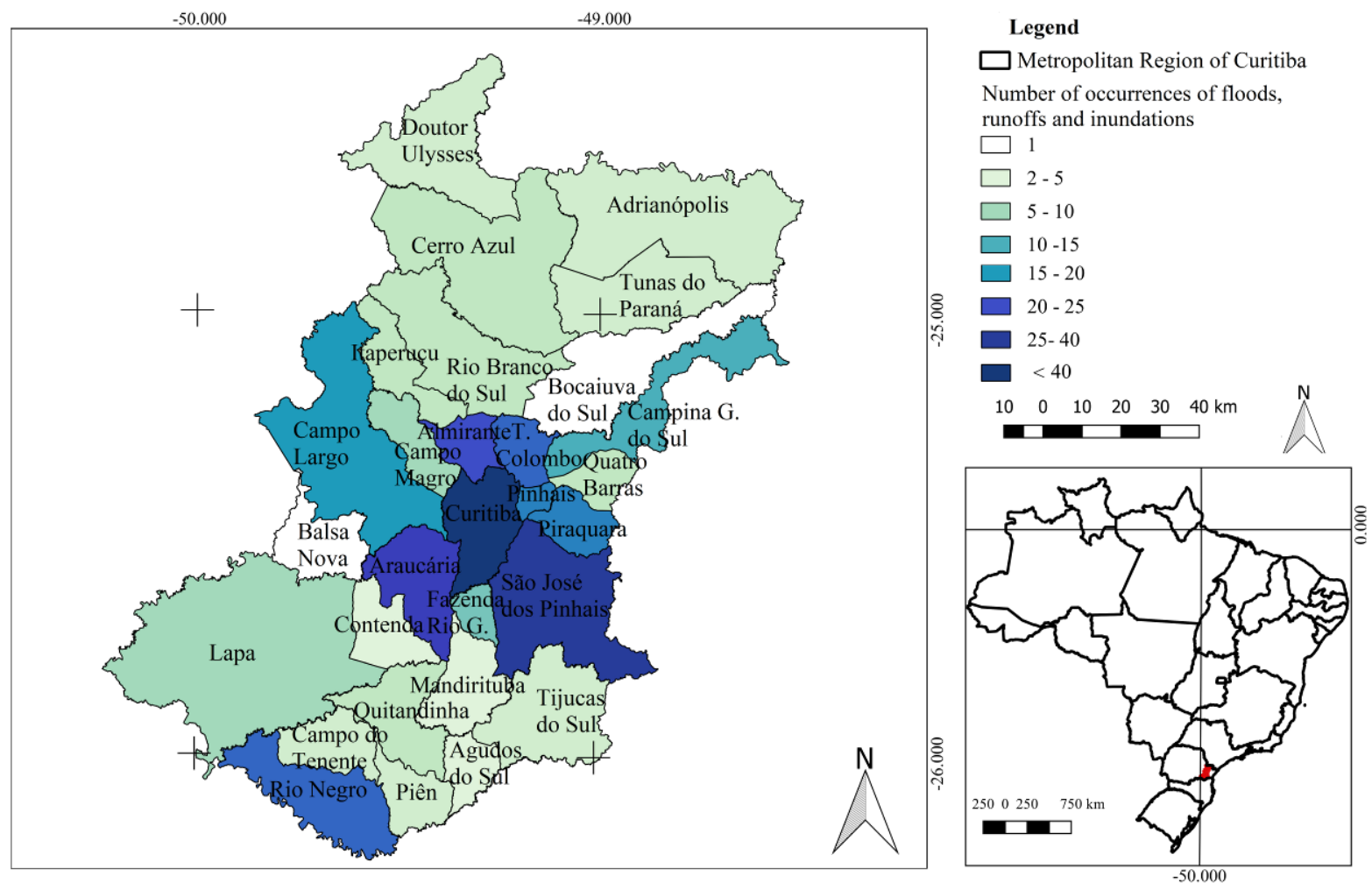

Source: Paraná State Civil Protection and Defense Coordination (2018); Org. authors (2019).

Of these events, some can be so disastrous that the municipalities declare an Emergency Situation or Public Disaster (Figure 07), showing the legal recognition by the municipality affected of an abnormal situation caused by disasters. The emergency situation is characterized by the fact that it is bearable and surmountable damage by the affected community, while in Public Calamity the damage is not only social but also brings high risk to life. Its damages are difficult to repair, only being overcome with the help of governments and external bodies (CASTRO, 1998). Altogether there were 48 decrees in the region, one of which was a public calamity.

Only 9 of the 29 municipalities did not declare an emergency or public calamity in the region, from 1990 to 2018 . The municipality with the highest number of decrees was Rio Negro with seven, the only one to declare a state of Public Calamity on June 9, 2014, in a flood-related event. 
Figure 7 - Number of Decrees on Emergency Situations and Public Calamity linked to by floods, inundations and runoff in the Metropolitan Region of Curitiba (1990 - 2018).

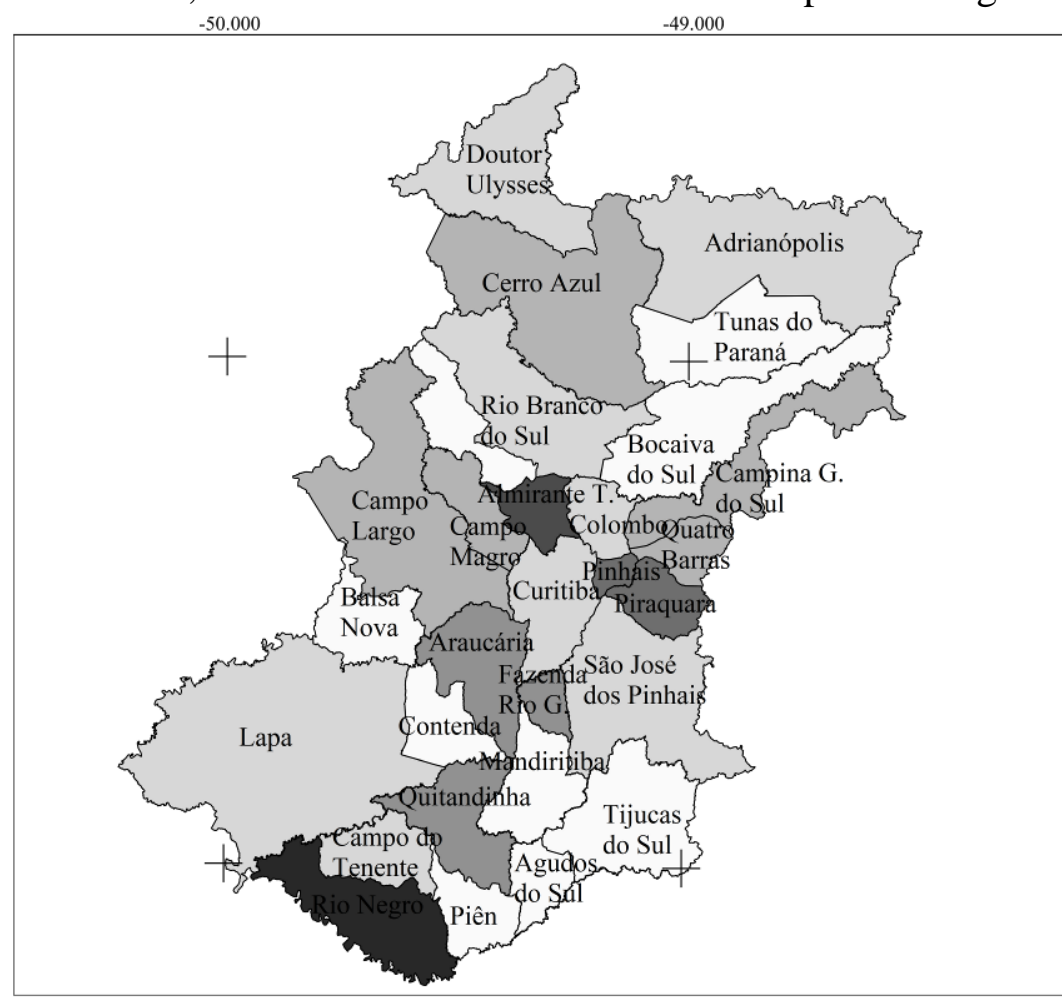

Legend

$\square$ Metropolitan Region of Curitiba

Number of Decrees on Emergency Situations and Public Calamity linked to by floods, inundations and runoff

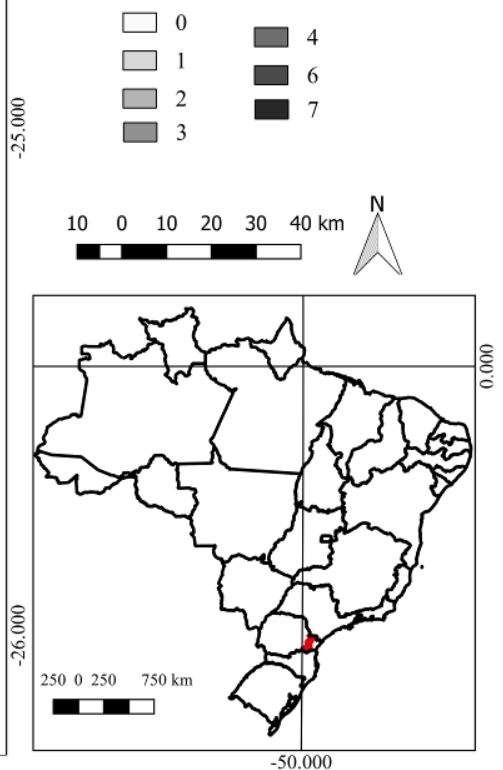

Source: Paraná State Civil Protection and Defense Coordination (2018); Org. authors (2019).

Then, the municipality of Almirante Tamandaré appears with six decrees of emergency situation, followed by Pinhais and Piraquara with four decrees each. Curitiba showed only an emergency situation decree on June 20, 2013, linked to flooding.

Altogether there were 17 deaths caused by one of the three socio-environmental disasters, with the municipalities with the highest number of deaths, Fazenda Rio Grande, Rio Negro and São José dos Pinhais, with 3 each.

People are the ones who suffer most from the disasters caused by the rains, which suffer the impacts directly and indirectly. In this sense, the number of people affected by floods, runoff or floods (Figure 08), was 397,516, from 1990 to 2018 in the MRC. The most affected municipality was Curitiba, with 87,507 people affected. The high numbers of the capital of Paraná are due to the fact that it is the most populous, and therefore those who are at greater risk and vulnerable to impacts, within the municipalities analyzed. Curitiba has 1,917,185 inhabitants (IBGE, 2018). Then, Almirante Tamandaré appears with 86,005 inhabitants who suffered some damage from one of the three events, counting a population of 117,168 (IBGE, 2018). In the central area of the region, Pinhais also stands out with 79,598 affected people and a population of 129,445 inhabitants (IBGE, 2018). 
Figure 8 - Number of people affected by floods, inundations and runoff in the Metropolitan Region of Curitiba (1990 - 2018).
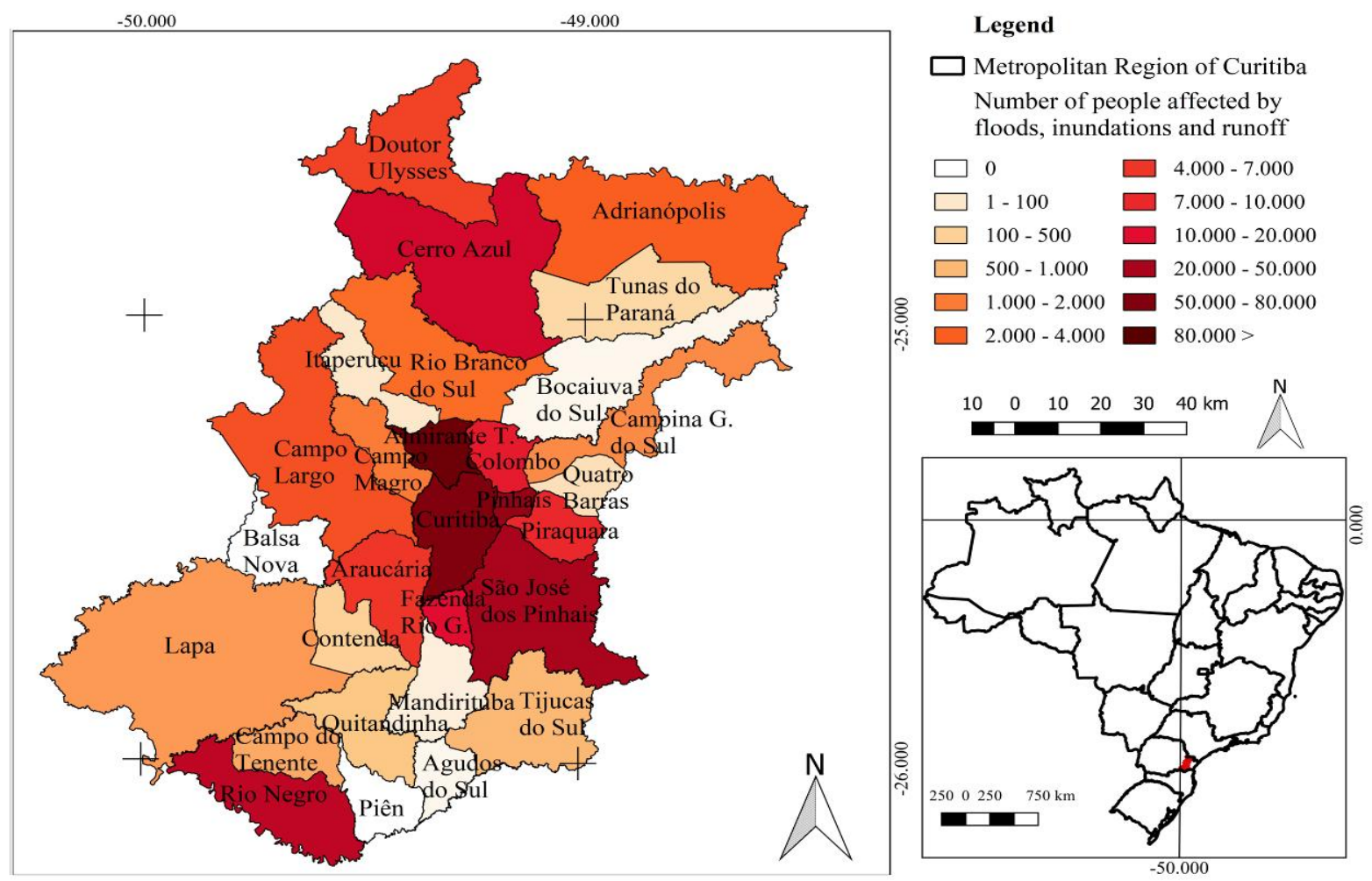

Source: Paraná State Civil Protection and Defense Coordination (2019); Org. authors (2019).

Less developed and less demographic cities also registered decrees due to disasters. It is worth mentioning that the size of the municipalities and the number of people residing there does not rule out the possibility of a disaster occurring due to extreme precipitation events. Among the small towns in the region, Rio Negro stands out with 25,043 affected people and a population of 31,261 inhabitants and Cerro Azul with 20,626 affected people and a population of 16,948 inhabitants (IBGE, 2018). The latter, proportionally being the municipality most affected in the MRC, and also demonstrating that part of the population was affected more than once by any of the episodes in the municipality.

In the Metropolitan Region of Curitiba, as in most Brazilian metropolises, the risks in the urban space associated with climatic events are often linked to the rapid process of urbanization and civil construction. Curitiba, mainly, after the 1970s, had its population increased abruptly and received a range of migrants, in many cases, "bearers of low technical and educational preparation and less financially well-off", being subjected by the city's real estate market to a proliferation from peripheral neighborhoods, often in irregular occupations and in dwellings with little preparation for the climatic adversities that occur in the city, such 
as floods, runoff, inundation, gales and hail. Thus, this portion of the population started to live with several types of environmental impacts and risks, characterized as "socio-environmental vulnerability" (MENDONÇA, 2005, p. 143; CIDADE, 2013; MENDONÇA et al., 2016; WILK et al., 2018).

Problems with floods, inundation and runoff are frequent throughout the world, and as mentioned, representing at least $80 \%$ of Brazilian cities. In recent decades, these events have gained public attention and investments in infrastructure, concentrated mainly in large cities (MARCELINO, 2007 CHEN, et al. 2018). At the MRC the problems caused are notorious and alarming, they were present in at least $90 \%$ of the municipalities. The planning of this region must always be carried out with measures aimed at improving urban drainage, thus mitigating this type of occurrence, and consequently improving environmental and water quality.

Construction and housing sites may be linked to the number of people affected and the types of damage caused. The exposure of part of the regional population to the damage caused by these phenomena can be reduced, aiming mainly at improving the housing location in areas where the occurrence of floods, runoff and inundation are frequent.

Future work is necessary, focusing on the areas of Meteorology, Climatology, Hydrology and Urban Planning, mainly on the local scale, to identify in a morphometric analysis the most propitious places in these municipalities for this type of occurrence, thus assisting urban planning in this region. In addition, further studies that identify rainfall trends and extreme climatic events in the region would enable large-scale time planning.

And such studies gain greater magnitude in climate change scenarios. Urban centers should look for strategies and technologies to minimize impacts, whether social or environmental. And cities with reduced development size should focus on seeking to increase the resilience of the population to overcome these adversities.

\section{Final Considerations}

Precipitation in the Metropolitan Region of Curitiba proved to be well distributed regionally, but with greater heights in the mountain range. It was identified that extreme rain events, by the two methods of analysis, are striking during all months. In the Campo Largo, Doutor Ulysses and São José dos Pinhais stations, the occurrence of extreme events in the 
Summer months predominated, while in the Rio Negro station, located far Southern in the region, events formed in the Fall and Winter months predominated. Events of months without precipitation are concentrated during the Fall and Winter.

The responses of these extreme precipitation events on the surface are noticeable through floods, runoffs and inundation. In total there were 368 occurrences, 48 decrees and 397 thousand people affected by at least one of the three disasters. Curitiba was the most affected municipality with 46 occurrences, followed by Araucária and São José dos Pinhais. Rio Negro was the only municipality to register a state of public calamity due to a flood event, in which the municipality was unable to repair the damage caused by the extreme event. Curitiba, having due the higher population when compared to the others, was the one that had the most people who suffered damage from the events, with 87,507 people affected. However, proportionally, the municipality most affected was Cerro Azul with 20,626 affected people and a population of 16,948 inhabitants, demonstrating that the event reached more than once the same person in 28 years of analysis. The vulnerability and risks of natural disasters caused in the urban space are alarming and should assist in planning and decisionmaking in the MRC, aiming mainly at improvements in urban drainage and housing.

Disasters notably occur due to urban planning, which often does not have mechanisms to reduce the impacts of extreme rainfall. Depending on the intensity of rainfall, disasters are inevitable, however, most cases can be remedied with effective and robust urban planning, especially in urban areas that are highly vulnerable. It stands out here, the role of the civil defense in providing quick assistance in order to minimize the impacts.

\section{References}

AGOVINO, M. et al. Agriculture, climate change and sustainability: The case of EU-28. Ecological Indicators, 2018.

ALBUQUERQUE, F. da S. et al. Aptidão climática de culturas agrícolas importantes para comunidades indígenas do semiárido brasileiro. Irriga, v. 22, n. 1, p. 59, 2018.

ALCÁNTARA-AYALA, I. Geomorphology, natural hazards, vulnerability and prevention of natural disasters in developing countries. Geomorphology, v. 47, p. 107 - 124, 2002.

BALDO, M. C. et al. Variabilidade Pluviométrica na Bacia do Rio Mourão-PR. Perspectiva Geográfica, v. 12, n. 17, p. 135-152, 2017. 
BEREZUK, A. G.; SANT'ANNA NETO, J. M. Eventos climáticos extremos no oeste paulista e norte do Paraná, nos anos de 1997, 1998 e 2001. Revista Brasileira de Climatologia, v. 2, p. $153-164,2006$.

BEREZUK, A. G. Eventos Extremos: Estudo da Chuva de Granizo de 21 de Abril de 2008 na Cidade de Maringá-PR. Revista Brasileira de Climatologia, v. 5, p. 9-22, 2017.

BERLATO, M. A.; FONTANA, D. C. El Niño e La Niña: impactos no clima, na vegetação e na agricultura do Rio Grande do Sul; aplicações de previsões climáticas na agricultura. Porto Alegre: Ed. da UFRGS, 2003. 110p.

CALDANA, N. F. S. et al. Ocorrências de Alagamentos, Enxurradas e Inundações e a Variabilidade Pluviométrica na Bacia Hidrográfica do Rio Iguaçu. Revista Brasileira de Climatologia, v. 23, p. 343-355, 2018.

Frequência, Intensidade e Variabilidade Pluviométrica na Mesorregião Sudoeste Paranaense. Revista Brasileira de Climatologia, v. 25, p. 161-181, 2019.

CALDANA, N. F. S.; MARTELÓCIO, A. C. Gênese, frequência e intensidade das precipitações de granizo nas Mesorregiões Centro Oriental e Sudeste Paranaense, Brasil. Geotextos, v. 15, p. 205-229, 2019.

CARAMORI, P. H. et al. Zoneamento de riscos climáticos para a cultura do café (Coffea arabica L.) no Paraná. Revista Brasileira de Agrometeorologia, Santa Maria, v. 9, n. 3, p.486-494, 2001.

CARVALHO, A. A. et al. Zoneamento agrometeorológico da moringa para o Estado de Pernambuco em condições atuais e projeções futuras. Journal of Environmental Analysis and Progress, v. 2, n. 3, p. 194-202, 2017.

CASTRO, A. L. C. de. Glossário de Defesa Civil: estudos de riscos e medicina de desastres. Ministério do Planejamento e Orçamento, Secretaria Especial de Políticas Regionais, Departamento de Defesa Civil, 1998.

CHEN, W. et al. Urban inundation response to rainstorm patterns with a coupled hydrodynamic model: A case study in Haidian Island, China. Journal of Hydrology, v. 564, p. 1022-1035, 2018.

CIDADE, L. C. F. Urbanização, ambiente, risco e vulnerabilidade: em busca de uma construção interdisciplinar. Cadernos Metrópole, v. 15, n. 29, p. 171-191, 2013.

CONTI, J. B. Considerações sobre as mudanças climáticas globais. In: Revista do Departamento de Geografia, São Paulo, v. 16, 2005, p.70-75.

CONCEIÇÃO, M. A. F. Índices hídricos climáticos para a viticultura. Pesquisa Agropecuária Brasileira, v. 53, n. 6, p. 765-768, 2018. 
COUTO, F. T. et al. Numerical simulations of significant orographic precipitation in Madeira island. Atmospheric Research, v. 169, p. 102-112, 2016.

DAFIS, S. et al. Observational and modeling study of a mesoscale convective system during the HyMeX - SOP1. Atmospheric Research, v. 187, p. 1-15, 2017.

DAMASCENA, A. P. et al. Zoneamento Agroclimático Para o Cultivo do Abacaxi no Espírito Santo Mediante Interpolação Espacial. Revista Univap, v. 22, n. 40, p. 327, 2017.

DOURTE, D. R. et al. Exploring changes in rainfall intensity and seasonal variability in the Southeastern US: Stakeholder engagement, observations, and adaptation. Climate Risk Management, v. 7, p. 11-19, 2015.

ELY, D. F.; DUBREUIL, V. Análise das Tendências espaço-temporais das precipitações anuais para o estado do Paraná - Brasil. Revista Brasileira de Climatologia, Curitiba, 553569, v. 21, 2017.

FREIRE, N. B. C. et al. Vulnerabilidade socioambiental, inundações e repercussões na Saúde em regiões periféricas: o caso de Alagoas, Brasil. Ciência \& Saúde Coletiva, v. 19, p. 37553762, 2014.

GELCER, E. et al. Influence of El Niño-Southern oscillation (ENSO) on agroclimatic zoning for tomato in Mozambique. Agricultural and forest meteorology, v. 248, p. 316-328, 2018.

GRIGOLETTI, G. de C. et al. Microclima urbano de áreas residenciais no período noturno: Estudo em Santa Maria, RS. Revista Sociedade \& Natureza, v. 30, n. 2, p. 140-163, 2018.

HUANG, K. et al. Flood hydrograph coincidence analysis for mainstream and its tributaries. Journal of Hydrology, v. 565, p. 341-353, 2018.

KARIMI, V. et al Vulnerability and Adaptation of Livestock Producers to Climate Variability and Change. Rangeland Ecology \& Management, v. 71, n. 2, p. 175-184, 2017.

KARIMI, V. Climate change and agriculture: Impacts and adaptive responses in Iran. Journal of Integrative Agriculture, v. 17, n. 1, p. 1-15, 2018.

HUANG, K. et al. Flood hydrograph coincidence analysis for mainstream and its tributaries. Journal of Hydrology, v. 565, p. 341-353, 2018.

IBGE (Fundação Instituto Brasileiro de Geografia e Estatística), 2018. Censo Demográfico: Brasil, 2017. Rio de Janeiro: IBGE.

IPCC. Technical Summary. In: Climate Change 2013: The Physical Science Basis. Contribution of Working Group I to the Fifth Assessment Report of the Intergovernmental Panel on Climate Change. Cambridge University Press, Cambridge, United Kingdom and New York, NY, USA, 2013. 
LEE, J. et al. Enhancement of orographic precipitation in Jeju Island during the passage of Typhoon Khanun (2012). Atmospheric Research, v. 201, p. 58-71, 2018.

LEM, S. et al. The heuristic interpretation of box plots. Learning and Instruction, v. 26, p. 22-35, 2013.

LUNGARSKA, A.; CHAKIR, R. Climate induced land use change in France: impacts of agricultural adaptation and climate change mitigation. Ecological Economics, v. 147, p. 134$144,2018$.

MACHADO, T. da S. et al. Zoneamento Agroclimático do Melão na Região Sudoeste de Mato Grosso. Revista Brasileira de Climatologia, v. 20, p. 169-181, 2017.

MANCILLAS, R. G. et al. Zonificación edafoclimática para el cultivo de Jatropha curcas L., en Tabasco, México. Investigaciones Geográficas, Boletín del Instituto de Geografía, v. 2015, n. 86, p. 25-37, 2015.

MARCELINO, E. V.; Desastres Naturais e Geotecnologias: Conceitos Básicos. INPE, Santa Maria, 2007.

MARTINS, J. A. et al. Climatology of destructive hailstorms in Brazil. Atmospheric Research, v. 184, p. 126-138, 2017.

DE MATOS, R. M. et al. Agroclimatic Potential For Mango Culture in the Municipality of Barbalha CE. Revista Brasileira de Agricultura Irrigada, v. 12, n. 1, p. 2366, 2018.

MENDONÇA, F. A. Riscos, vulnerabilidade e abordagem socioambiental urbana: uma reflexão a partir da RMC e de Curitiba. Desenvolvimento e Meio ambiente, v. 10, n. 10, p. $139-148,2005$.

MENDONÇA, F. A. et al. Resiliência socioambiental-espacial urbana a inundações: possibilidades e limites no bairro Cajuru em Curitiba (PR). Revista da ANPEGE, v. 12, n. 19, p. 279-298, 2016.

MINUZZI, R. B. CARAMORI, P. H. Variabilidade climática sazonal e anual da chuva e veranicos no Estado do Paraná. Ceres, v. 58, n. 5, 2015.

MUELLER, T. G. et al. Map quality for ordinary kriging and inverse distance weighted interpolation. Soil Science Society of America Journal, v. 68, n. 6, p. 2042-2047, 2004.

NASCIMENTO JÚNIOR, SANT'ANNA NETO, J. L. Contribuição aos estudos da precipitação no estado do Paraná: a oscilação decadal do Pacífico-ODP. Raega-O Espaço Geográfico em Análise, v. 35, p. 314-343, 2016.

PAILLER, S.; TSANEVA, M. The effects of climate variability on psychological well-being in India. World Development, v. 106, p. 15-26, 2018. 
PANDOLFO, C. et al. Zoneamento agroclimático do mirtilo irrigado em Santa Catarina. Agropecuária Catarinense, v. 30, p. 84-88, 2017.

PASSOS, M. L. F. Balanço hídrico climatológico e classificação climática para o município de Balsas-Ma. Scientia agraria, v. 18, n. 1, p. 83-89, 2017.

PATHMESWARAN, C. et al. Impact of extreme weather events on coconut productivity in three climatic zones of Sri Lanka. European Journal of Agronomy, v. 96, p. 47-53, 2018.

PUNGE, H. J.; KUNZ, M. Hail observations and hailstorm characteristics in Europe: A review. Atmospheric Research, v. 176, p. 159-184, 2016.

DOS REIS, L. S. et al. Zoneamento agroclimático de cultivos com potencial energético no estado de Minas Gerais. Revista Espinhaço, p. 50-63, 2017.

SANCHES, F. de O., VERDUM, R., FISCH, G. Tendência de longo prazo das chuvas diárias no Sudoeste do Rio Grande do Sul: os eventos extremos e a arenização. Revista Brasileira de Geografia Física, v. 7, n. 6, p. 1100-1109, 2014.

SANTI, A. et al. Impacto de cenários futuros de clima no zoneamento agroclimático do trigo na região Sul do Brasil. Agrometeoros, v. 25, n. 2, p. 303-311, 2018.

SCAGLIONI, T. P.; SARAIVA, J. M. B. Climatologia dos sistemas precipitantes para o período de fevereiro a dezembro de 2003, no Rio Grande do Sul. In: Congresso Brasileiro De Meteorologia. 2004.

SCHNEIDER, H.; DA SILVA, C. A. O uso do modelo box plot na identificação de anospadrão secos, chuvosos e habituais na microrregião de Dourados, Mato Grosso do Sul. Revista do Departamento de Geografia, v. 27, p. 131-146, 2014.

SOMBOONSUKE, B. et al. Farmers' perceptions of impacts of climate variability on agriculture and adaptation strategies in Songkhla. Kasetsart Journal of Social Sciences, v. 39, n. 2, p. 277-283, 2018.

DE SOUSA, J. W.; DE OLIVEIRA, P. F. Risco climático para o café Conilon (Coffea canephora) nos municípios de Rio Branco, Tarauacá e Cruzeiro do Sul, AC. Revista Brasileira de Ciências da Amazônia/Brazilian Journal of Science of the Amazon, v. 7, n. 2, p. 31-40, 2018.

DE SOUZA, D. C. F. et al. Zoneamento Agroclimático da Palma Forrageira (Opuntia Sp) Para o Estado de Sergipe. Revista Brasileira de Agricultura Irrigada, v. 12, n. 1, p. 2338, 2018.

TAYT'SOHN, F. C. O. Assessing sugarcane expansion to ethanol production under climate change scenarios in Paranaíba river basin-Brazil. Biomass and Bioenergy, v. 119, p. 436445, 2018. 
TREFALT, S. et al. A Severe Hail Storm in Complex Topography in SwitzerlandObservations and Processes. Atmospheric Research, v. 209, p. 76-94, 2018.

WILK, J. et al. The perspectives of the urban poor in climate vulnerability assessments-The case of Kota, India. Urban climate, v. 24, p. 633-642, 2018.

WIRÉHN, L. Nordic agriculture under climate change: A systematic review of challenges, opportunities and adaptation strategies for crop production. Land Use Policy, v. 77, p. 63-74, 2018.

Artigo recebido em 20-09-2020 Artigo aceito para publicação em 13-07-2021 